\author{
BogdAN DOLNICKI ${ }^{1}$
}

\title{
Prawo zabudowy a planowanie i zagospodarowanie przestrzenne
}

\section{Istota prawa zabudowy}

Zasada wolności budowlanej uznawana jest za podstawową zasadę polskiego prawa budowlanego ${ }^{2}$. Przypisuje się jej rolę zbliżoną do tej, jaką odgrywa zasada wolności gospodarczej w sferze obrotu gospodarczego ${ }^{3}$. Poszukując jej normatywnych podstaw, należy w pierwszej kolejności odwołać się do uregulowań ustawy zasadniczej. Tekst Konstytucji RP nie zawiera określeń „wolności budowlanej” ani wynikającego z niej wolnościowego „prawa zabudowy”. Brak literalnych odniesień do wyżej wskazanych pojęć nie przesądza jednak o braku intencji ustawodawcy w zapewnieniu wolności budowlanej prawnej ochrony. Prawo zabudowy z racji swojego charakteru powinno być wiązane z prawami do rzeczy, a ściślej - do nieruchomości ${ }^{4}$.

Wśród regulacji konstytucyjnych na szczególną uwagę zasługują te poświęcone prawu własności jako najsilniejszemu z praw rzeczowych. Rozpatrywanie prawa zabudowy nie może się zatem odbywać bez uprzedniego przyjrzenia się uksztaltowaniu prawa własności w porządku prawnym. Najdonioślejsze znaczenie w tym aspekcie mają unormowania zawarte w art. 20, 21, 31 i 64 Konstytucji RP ${ }^{5}$. Oparcie ustroju Rzeczypospolitej o model społecznej gospodarki rynkowej, której nieodzownym elementem jest własność prywatna, stanowi istotne zabezpieczenie interesów obywateli. Ustawodawca nałożył bowiem na organy władzy obowiązek stworzenia ram prawnych zapewniających ochronę wolności, praw i innych wartości konstytucyjnych ${ }^{6}$, wyróżniając przy tym w sposób szczególny potrzebę ochrony własności. Jednocześnie dla zapewnienia możliwości nieskrępowanego korzystania z rzeczy

$1 \quad$ Uniwersytet Śląski w Katowicach.

2 R. Hauser, Z. Niewiadomski, Konstytucyjne aspekty regulacji procesu inwestycyjno-budowlanego, „Państwo i Prawo" 2015, nr 6, s. 3.

3 Z. Niewiadomski (red.), Prawo budowlane. Komentarz, Warszawa 2015, s. 89.

$4 \quad$ W. Jakimowicz, Wolność zabudowy w prawie administracyjnym, Warszawa 2012, s. 48.

$5 \quad$ Konstytucja Rzeczypospolitej Polskiej z 2 kwietnia 1997 r., Dz.U. Nr 78, poz. 483, ze zm.

6 R. Hauser, Z. Niewiadomski, Konstytucyjne..., op. cit., s. 4. 
na podstawie innych niż własność tytułów prawnych, rozszerzył zakres ochrony także na inne prawa majątkowe (przysługujące np. z tytułu użytkowania wieczystego, najmu czy dzierżawy, wiążących się z uprawnieniem do dysponowania nieruchomością na cele budowlane). Samo prawo własności w ujęciu konstytucyjnym ujmowane jest jako wolność, na którą składają się: wolność majątkowa oraz wolność od ingerencji władz publicznych i innych podmiotów ${ }^{7}$. Podejście zaliczające własność do kategorii wolności obywatelskich pozwala traktować własność obiektywnie jako zasadę ustrojową stanowiącą podstawę do interpretacji innych przepisów, jak również subiektywnie, uznając ją za prawo podmiotowe jednostki ${ }^{8}$. Prawo podmiotowe oznacza przyznaną lub zagwarantowaną przez normy prawne korzystną sytuację jednostki ${ }^{9}$. Wyróżnić można prawa podmiotowe publiczne, których istotą jest możliwość żądania od państwa (organów administracji publicznej) zaniechania nieuprawnionej ingerencji, a także prawa podmiotowe prywatne pozwalające na korzystanie $\mathrm{z}$ tego prawa ${ }^{10}$. Prawo własności cechuje się interdyscyplinarnym charakterem, a zatem może być traktowane zarówno jako publiczne prawo podmiotowe, jak i prywatne prawo podmiotowe. W tym pierwszym rozumieniu, zawartym w Konstytucji, prawu własności nadawana jest treść negatywna poprzez podkreślenie ochronnej funkcji przepisów ustawy zasadniczej i ustalenie restrykcyjnego katalogu podstaw do nałożenia ograniczeń prawa własności. Cywilnoprawne rozumienie prawa własności przyjmuje natomiast postać otwartego zbioru uprawnień przysługujących właścicielowi, wzbogaconego o aspekt negatywny będący refleksem pojmowania prawa własności jako prawa bezwzględnego skutecznego erga omnes.

Prawo zabudowy nieruchomości mieści się w pojęciu korzystania z rzeczy ${ }^{11}$. Pojmowanie prawa zabudowy wyłącznie jako przejawu korzystania z rzeczy na podstawie prawa własności jest jednak zbyt wąskim ujęciem i nie odzwierciedla go w pełni. Trzeba mieć na uwadze, że prawo zabudowy przysługuje nie tylko właścicielowi, ale także innym podmiotom, które co prawda nie legitymują się tym najsilniejszym tytułem prawnym do nieruchomości, ale korzystają z niej na innej podstawie. Podmioty te działają niejako w pewnej sferze prawnej właściciela ograniczonej przez normy prawne, a także postanowienia zawieranych umów. Wyrazem takiego szerokiego pojmowania zakresu podmiotowego prawa zabudowy nieograniczonego jedynie do osoby właściciela jest brzmienie art. 4 Prawa budowlanego ${ }^{12}$ statuującego w polskim porządku prawnym zasadę wolności budowlanej: „Każdy ma prawo zabudowy nieruchomości gruntowej, jeżeli wykaże prawo do dysponowania nieru-

J. Ciapała, Konstytucyjna regulacja praw podmiotowych. Podstawowe konsekwencje dla ustawodawcy, (w:) J. Ciapała, K. Flaga-Gieruszyńska (red.), Prawa podmiotowe. Pojmowanie w naukach prawnych. Zbiór studiów, Szczecin 2006, s. 43.

W. Jakimowicz, Wolność..., op. cit., s. 55.

Z. Niewiadomski (red.), Prawo budowlane..., op. cit., s. 90.

Tamże.

Z. Niewiadomski (red.), Prawo budowlane..., op. cit., s. 93.

Ustawa z dnia 7 lipca 1994 r. Prawo budowlane, Dz.U. z 2016 r. poz. 290, ze zm. 
chomością na cele budowlane, pod warunkiem zgodności zamierzenia budowlanego z przepisami”.

Kryterium podmiotowe przyznania prawa zabudowy w postaci „,wykazania prawa do dysponowania nieruchomością na cele budowlane" może spełniać nie tylko właściciel lub współwłaściciele, ale również użytkownik wieczysty, zarządca, użytkownik, uprawniony z tytułu służebności, praw spółdzielczych czy też ze stosunku zobowiązaniowego (przede wszystkim najmu i dzierżawy).

Określenie istoty prawa zabudowy sprowadza się do sprecyzowania zakresu dopuszczalnych ingerencji $w$ to prawo. Swoiste powiązanie prawa zabudowy nieruchomości z korzystaniem z rzeczy w ramach wykonywania prawa własności każe w każdym indywidualnym przypadku uwzględniać kontekst sytuacji, w której to prawo się przejawia ${ }^{13}$. Szczególnym zagadnieniem jest kwestia wpływu działań podejmowanych przez organy administracji publicznej na prawo własności, w tym prawo zabudowy nieruchomości. Wykonywanie powierzonych kompetencji przy wykorzystaniu władztwa planistycznego niejednokrotnie prowadzi do konfliktu pomiędzy interesem publicznym a interesem prywatnym.

Władztwo planistyczne gminy może być określone jako przekazanie gminie kompetencji w zakresie władczego przeznaczania i ustalania zasad zagospodarowania terenu ${ }^{14}$. Na pojęcie władztwa planistycznego składają się zatem trzy elementy: możliwość władczego oddziaływania na prawa i obowiązki jednostki, źródło władztwa w postaci upoważnienia ustawowego oraz sama jego treść ${ }^{15}$. Władztwo planistyczne nie jest prawem nieograniczonym. Naczelną regułą, którą winien kierować się organ administracji, jest racjonalne wyważenie określonych wartości. Realizując zadania, musi on dążyć do przyznania należytego miejsca interesowi publicznemu (a więc zaspokajania potrzeb zbiorowości), przy jednoczesnym poszanowaniu interesu indywidualnego. Wszystkie działania muszą być przeprowadzane w granicach prawa, przy zastosowaniu zasady proporcjonalności ingerencji.

\section{Ograniczenia prawa zabudowy a nadużycie władztwa planistycznego}

Plan miejscowy będący aktem prawa miejscowego w istotny sposób wpływa na wykonywanie uprawnień właścicielskich. Ograniczenie prawa zabudowy przejawia się przede wszystkim w zakazie zagospodarowania terenu przez właścicieli w sposób sprzeczny z ustaleniami planu. Ponadto, akt ten określa warunki dokonywania podziałów i scaleń nieruchomości, a także - w wyjątkowych przypadkach

\footnotetext{
13 W. Jakimowicz, Wolność..., op. cit., s. 70.

14 Z. Niewiadomski (red.), Planowanie i zagospodarowanie przestrzenne. Komentarz, Warszawa 2009, s. 30.

15 J. Parchomiuk, Nadużycie władztwa planistycznego gminy, „Samorząd Terytorialny” 2014, nr 4, s. 22.
} 
uzasadnionych przeznaczeniem terenów pod cele publiczne - może stanowić podstawę wywłaszczenia, godzącego w samą istotę prawa zabudowy.

Granice władztwa planistycznego w kontekście zapewnienia poszanowania konstytucyjnie chronionego prawa własności są niezwykle trudne do wyznaczenia. Podstawowe znaczenie dla ochrony własności ma - w myśl orzecznictwa TK ${ }^{16}$ - art. 31 ust. 3 Konstytucji stanowiący: „Ograniczenia w zakresie korzystania z konstytucyjnych wolności i praw mogą być ustanawiane tylko w ustawie i tylko wtedy, gdy są konieczne w demokratycznym państwie dla jego bezpieczeństwa lub porządku publicznego, bądź dla ochrony środowiska, zdrowia i moralności publicznej, albo wolności i praw innych osób. Ograniczenia te nie mogą naruszać istoty wolności i praw”. Potwierdzeniem dopuszczalności stosowania ograniczeń prawa własności jest art. 64 ust. 3 Konstytucji, zgodnie z którym: „Własność może być ograniczona tylko w drodze ustawy i tylko w zakresie, w jakim nie narusza ona istoty prawa własności”. Art. 64 ust. 3 nie jest jednak przepisem szczególnym wyłączającym w tej materii art. 31 ust. 3 - dokonując oceny dopuszczalności ograniczeń, należy uwzględniać wymagania zawarte w obydwu przepisach.

Kierując się powyższymi podstawami prawnymi, można wskazać na następujące przesłanki legalnej ingerencji w prawo własności: zachowanie podstawy ustawowej, nienaruszanie istoty prawa własności, uzasadnienie ograniczenia, zachowanie zasady proporcjonalności ${ }^{17}$. Rozważania dotyczące kierowania się przez gminę zasadą proporcjonalności przy prowadzeniu polityki przestrzennej doprowadziły do wykształcenia się w doktrynie koncepcji nadużycia władztwa planistycznego. Dotyczy to sytuacji przekroczenia przez organy gminy granic przyznanej im samodzielności w sferze planowania przestrzennego. Sądy administracyjne wskazują w głównej mierze na nieproporcjonalność ingerencji, brak wyważenia kolidujących wartości, nieuzasadnione i sprzeczne z zasadą równości różnicowanie sytuacji prawnej właścicieli znajdujących się w takiej samej sytuacji, a także uchybienie zasadzie sprawiedliwości społecznej przy ewentualnym (w razie braku innych dostępnych rozwiązań) ograniczaniu uprawnień jednostek ${ }^{18}$. Proporcjonalność jawi się jako główny wzorzec legalności miejscowych planów zagospodarowania przestrzennego.

Ingerencja w prawo własności, nawet ta względnie głęboka, mieści się w konstytucyjnym porządku demokratycznego państwa prawnego. Za nadużycie władztwa z pewnością nie może być uznane samo korzystanie z niego w sposób nieodpowiadający oczekiwaniom zainteresowanych właścicieli nieruchomości. Podstawowym założeniem, którym powinna kierować się gmina podejmując działania godzące w jednostkowe prawa i wolności, jest rozsądne wyważenie kolidujących interesów

$16 \quad$ Wyrok TK z dnia 12 stycznia 1999 r., P 2/98, Dz.U. Nr 3, poz. 30.

17 P. Kociubiński, Powojenne przekształcenia własnościowe w świetle Konstytucji, Warszawa 2013 , s. 101.

18 Por. J. Parchomiuk, Nadużycie..., op. cit., s. 30 i powoływane tam orzecznictwo. 
i poszukiwanie kompromisowych rozwiązań. Do przekroczenia granic władztwa dojdzie dopiero wtedy, gdy rozwiązania te będą cechowały się nieskrępowaną arbitralnością, dowolnością oraz brakiem ekonomicznego, społecznego i aksjologicznego uzasadnienia ${ }^{19}$.

\section{Wpływ unormowań planistycznych na prawo własności}

Przyjęcie założenia, że gminie przysługuje prawo do władczego wkraczania w prawa i wolności poszczególnych jednostek uzasadnia pytanie o wpływ tej ingerencji na treść i wykonywanie prawa własności. Na mocy ustawowego upoważnienia miejscowy plan zagospodarowania przestrzennego, w sensie formalnym będący aktem podustawowym, nabiera w sensie materialnym rangi ustawy. $\mathrm{Na}$ tej podstawie jego postanowienia mogą władczo ustalać sposób zagospodarowania nieruchomości i tym samym oddziaływać na ich społeczno-gospodarcze przeznaczenie, co dla właściciela może przejawiać się w różnego rodzaju ograniczeniach sposobu korzystania z nieruchomości ${ }^{20}$. O tym, jakiego rodzaju unormowania zawiera plan miejscowy, przesądza art. 15 ust. 2 u.p.z.p. Przez ograniczenia należy więc rozumieć np. określenie zasad i warunków, które musi spełniać powstająca na danym terenie zabudowa, wprowadzenie całkowitego zakazu zabudowy lub zakazu zabudowy obiektów określonego rodzaju. Każde z tych ograniczeń sprowadza się jednak do zakazu zagospodarowania w sposób inny niż przewidziany, w żadnym wypadku nie może być natomiast traktowane jako nakaz podjęcia przez właściciela działań zmierzających do zmiany stanu istniejącego na wskazany w akcie planistycznym. Właściciele nieruchomości nie mają bowiem pozytywnego obowiązku realizacji zagospodarowania ustalonego w nowo uchwalonym planie. Plan miejscowy może także ograniczać w swobodnym rozporządzaniu przedmiotem prawa własności, przede wszystkim poprzez wyznaczenie dopuszczalnej wielkości działek czy określenie kryteriów dokonywania podziałów i scaleń nieruchomości.

Najdalej idącym ograniczeniem prawa własności dokonywanym w planie miejscowym jest faktyczne wyzucie z tego prawa. Choć instytucja wywłaszczenia jest $\mathrm{w}$ polskim porządku prawnym uregulowana $\mathrm{w}$ ustawie o gospodarce nieruchomościami, na gruncie planowania i zagospodarowania przestrzennego może dojść do ustalenia takich warunków użytkowania nieruchomości, że właściciel zostanie pozbawiony możliwości korzystania z niej w sposób ekonomicznie uzasadniony. Taką sytuację określa się mianem „wywłaszczenia faktycznego” albo „wywłaszczenia planistycznego" 21 . Poza kreowaniem treści i sposobu wykonywania prawa własności, skutki uchwalenia miejscowego planu rozciągają się także na prawa niemajątko-

19 Wyrok WSA w Krakowie z dnia 25 listopada 2011 r., II Sa/Kr 1381/11.

20 Z. Leoński, M. Szewczyk, M. Kruś, Prawo zagospodarowania przestrzennego, Warszawa 2012, s. 169.

21 M. Gdesz, Wywłaszczenie planistyczne, „Samorząd Terytorialny” 2014, nr 4, s. 52. 
we i wywierają wpływ na wartość ekonomiczną nieruchomości położonych na terenach objętych regulacją.

\section{Skutki uchwalenia planu miejscowego w zakresie praw niemajątkowych}

Uchwalenie planu miejscowego wiąże się z powstaniem skutków prawnych dla funkcjonowania decyzji lokalizacyjnych na terenie objętym planem. Jak stanowi art. 4 ust. 2 u.p.z.p., w przypadku braku planu miejscowego określenie sposobów zagospodarowania i warunków zabudowy terenu następuje w drodze decyzji o lokalizacji inwestycji celu publicznego lub decyzji o warunkach zabudowy i zagospodarowania terenu, wydawanych na wniosek inwestora. Przez „brak planu miejscowego” należy rozumieć zarówno nieprzystąpienie rady gminy do sporządzania planu, jak i sytuację, w której plan został wprawdzie uchwalony, lecz nie jest jeszcze wprowadzony do obrotu prawnego, a jego zapisy nie mają mocy obowiązującej. Oczywistą konsekwencją uchwalenia planu i jego wejścia w życie jest wobec tego niemożność ubiegania się o wyżej wymienione decyzje.

Nieco większej uwagi wymaga problematyka skutków uchwalenia planu miejscowego wywieranych na już istniejące w obrocie prawnym decyzje. Plan miejscowy pozbawia mocy prawnej decyzje lokalizacyjne wydane przed jego wejściem w życie, jeżeli ich ustalenia są inne niż zawarte w planie. W myśl art. 65 ust. 1 pkt 2 u.p.z.p. utrata mocy decyzji dokonywana jest w drodze stwierdzenia jej wygaśnięcia przez organ wydający. Stanowi to wyjątek od zasady trwałości ostatecznych i niewadliwych decyzji administracyjnych. Takie rozwiązanie motywowane jest pierwszeństwem postanowień planu nad ustaleniami indywidualnych decyzji o warunkach zabudowy odgrywających jedynie rolę jego substytutu. Uzyskanie decyzji lokalizacyjnej przez inwestora wiąże się z koniecznością poczynienia pewnych wstępnych formalnych przygotowań do zamierzenia budowlanego i z poniesieniem kosztów na wymagane uzgodnienia, sporządzenie kopii mapy zasadniczej lub katastralnej i opracowanie charakterystyki inwestycji. Na tym polu wyłania się wątpliwość, czy pozbawienie adresatów wydanych wcześniej decyzji nie pozbawia ich praw nabytych. Odpowiedź na to pytanie musi być przecząca, ponieważ decyzja o warunkach zabudowy nie rodzi praw do terenu oraz nie narusza prawa własności i uprawnień osób trzecich (art. 63 ust. 2 u.p.z.p.). Przesłanka wygaszająca różnice zawarte w ustaleniach planu miejscowego i decyzji oznacza odmienność w takim stopniu, że nie da się treści obu aktów pogodzić. Do wygaśnięcia decyzji o warunkach zabudowy nie może dojść, jeżeli inwestor zrealizował uprawnienia z niej wynikające i na jej podstawie uzyskał ostateczną decyzję o pozwoleniu na budowę. Pozwolenie na budowę korzysta w pełni z ochrony prawnej przewidzianej dla decyzji administracyjnych, stąd realizowana inwestycja może być nawet sprzeczna z przyjętym po wydaniu pozwolenia planem miejscowym. 


\section{RIGHT TO BUILD-UP A PLOT VS LAND-USE PLANNING AND MANAGEMENT}

Keywords: local government units, planning and spatial development, law of development, building freedom

The principle of freedom of construction is considered as a fundamental rule in the Polish Construction Law. In the search for its prescriptive basis, reference should be made primarily to the provisions of the Basic Law. The Polish Constitution does not include such terms as „freedom of construction" and "right to build-up a plot" arising under it. The lack of literal references to the abovementioned terms does not prejudge the intentions of the legislator to ensure the protection of freedom of construction by law.

The local spatial development plan, which serves as an act of local legislation, affects primarily the exercise of proprietary rights. Limitation on the right to buildup a plot is evident mainly in the prohibition of land-use by the owners in a manner that conflicts with the agreed spatial development plan. The limits of the planning authority in the context of guaranteeing the safeguarding.

\section{Bibliografia:}

Ciapała J., Konstytucyjna regulacja praw podmiotowych. Podstawowe konsekwencje dla ustawodawcy, (w:) J. Ciapała, K. Flaga-Gieruszyńska (red.), Prawa podmiotowe. Pojmowanie w naukach prawnych. Zbiór studiów, Szczecin 2006.

Gdesz M., Wywłaszczenie planistyczne, „Samorząd Terytorialny” 2014, nr 4, s. 52.

Hauser R., Niewiadomski Z., Konstytucyjne aspekty regulacji procesu inwestycyjno-budowlanego, „Państwo i Prawo” 2015, nr 6.

Jakimowicz W., Wolność zabudowy w prawie administracyjnym, Warszawa 2012.

Kociubiński P., Powojenne przekształcenia własnościowe w świetle Konstytucji, Warszawa 2013.

Leoński Z., Szewczyk M., Kruś M., Prawo zagospodarowania przestrzennego, Warszawa 2012.

Niewiadomski Z. (red.), Prawo budowlane. Komentarz, Warszawa 2015.

Niewiadomski Z. (red.), Planowanie i zagospodarowanie przestrzenne. Komentarz, Warszawa 2009.

Parchomiuk J., Nadużycie władztwa planistycznego gminy, „Samorząd Terytorialny” 2014, nr 4. 